\title{
World leaders are ignoring worldwide threat of Ebola, says MSF
}

\author{
Ingrid Torjesen
}

London

World leaders have failed to "come to grips" with the international threat posed by Ebola virus disease, warns an international humanitarian agency that has admitted it can't cope with the outbreak in west Africa.

Médecins Sans Frontières (Doctors Without Borders) has called for states with biological disaster response capacity, including civilian and military medical capability, to dispatch assets and personnel to west Africa immediately. MSF medical teams have been battling the outbreak in the region since March, caring for two thirds of the officially declared infected people, but they can't cope, said the international charity's president, Joanne Liu, at a special briefing on Ebola on 2 September at the United Nations headquarters in New York.

"Even as we have doubled our staff over the last month, I can tell you that they are completely overwhelmed," she said. "Six months into the worst Ebola epidemic in history, the world is losing the battle to contain it. Leaders are failing to come to grips with this transnational threat."

Despite MSF's repeated calls to countries worldwide for a massive mobilisation on the ground, "the response has been too little, too late," she said.

On 28 August the World Health Organization unveiled a plan aimed at stopping ongoing Ebola transmission within six to nine months. This roadmap acknowledged that nearly $40 \%$ of the total number of reported cases have occurred in the past three weeks, highlighting the urgent need to dramatically scale up the international response. WHO said that the roadmap was meant to serve as a framework for updating detailed operational plans and that it prioritised the need for treatment and management centres, social mobilisation, and safe burials.

But Liu said, "While funding announcements, roadmaps, and finding vaccines and treatments are welcome, they will not stop the epidemic today. We are in uncharted waters. Transmission rates are at unprecedented levels, and the virus is spreading quickly through Liberia's capital, Monrovia."

Liu said that, to curb the epidemic, countries needed to immediately deploy civilian and military assets with expertise in biohazard containment, in close collaboration with the affected countries. Field hospitals with isolation wards must be scaled up, trained personnel must be dispatched, and mobile laboratories must be deployed to improve diagnostics, she said.

Liu painted a grim picture of the current situation in areas affected by the Ebola virus: "Riots are breaking out. Isolation centres are overwhelmed. Health workers on the front lines are becoming infected and are dying in shocking numbers. Others have fled in fear, leaving people without care for even the most common illnesses. Entire health systems have crumbled.

"Ebola treatment centres are reduced to places where people go to die alone, where little more than palliative care is offered. It is impossible to keep up with the sheer number of infected people pouring into facilities. In Sierra Leone infectious bodies are rotting in the streets."

Coercive measures within affected countries, such as laws criminalising the failure to report suspected cases and forced quarantines, were driving the spread of the virus, she said. "This is leading to the concealment of cases and is pushing the sick away from health systems. These measures have only served to breed fear and unrest, rather than contain the virus," Liu added. She warned that the outbreak was "a transnational crisis, with social, economic, and security implications for the African continent" and that it was all countries" "responsibility to act."

"We cannot cut off the affected countries and hope this epidemic will simply burn out. To put out this fire we must run into the burning building," she said.

"We must also address the collapse of state infrastructure. The health system in Liberia has collapsed. Pregnant women experiencing complications have nowhere to turn. Malaria and diarrhoea, easily preventable and treatable diseases, are killing people. Hospitals need to be reopened and newly created."

Daniel Bausch, associate professor at the Tulane School of Public Health and Tropical Medicine in New Orleans and who has spent several months treating patients with Ebola virus disease, told The BMJ that the focus needed to be on improving routine care.

Bausch was in Guinea for most of April then in Sierra Leone in June and July. He is now working with various agencies to improve the response and, in particular, to train more healthcare workers.

Speaking to The BMJ from Lima, Peru, where he is head of virology and emerging infections at the Naval Medical Research Unit, Bausch described how the small healthcare staff on wards meant that it was "just not realistic" to provide the regular monitoring and fluid replacement that patients would receive if they were treated in Europe or the United States.

"These patients are losing lots and lots of fluids from diarrhoea especially, from vomiting, and sometimes from bleeding, so getting more fluids into them would certainly help," he said. 
He highlighted that in 1967 an outbreak in Germany of Marburg haemorrhagic fever-a disease similar to Ebola virus disease - had a death rate of $23 \%$. However, subsequent outbreaks in Africa, where patients had limited access to intensive care, have been associated with death rates of up to $90 \%{ }^{1}$

This view is shared by Jim Yong Kim, president of the World Bank, and Paul Farmer, who holds the Kolokotrones university professorship of global health and social medicine at Harvard University and who co-founded the non-profit organisation Partners in Health, in a comment piece in the Washington Post on 31 August. $^{2}$ They began, "If the Ebola epidemic devastating the countries of Guinea, Liberia and Sierra Leone had instead struck Washington, New York or Boston, there is no doubt that the health systems in place could contain and then eliminate the disease.

"Hospitals would isolate suspected cases. Health workers would be outfitted with proper protective clothing and equipment. Doctors and nurses would administer effective supportive care, including comprehensive management of dehydration, impaired kidney and liver function, bleeding disorders and electrolyte disturbance. Labs would dispose of hazardous materials properly. And a public health command center would both direct the response and communicate clearly to the public about the outbreak."

They added, "With a strong public health response led by the United Nations, the World Health Organization, the United States, Britain, France and other wealthy nations, the virus could be contained and the fatality rate-which, based on the most conservative estimates, exceeds $50 \%$ in the present outbreak-would drop dramatically, perhaps to below $20 \%$."

thebmj.com Feature: Ebola: an opportunity for a clinical trial? (BMJ 2014;349:g4997, doi:10.1136/bmj.g4997); Editorial: Ebola and other viral haemorrhagic fevers (BMJ 2014;349:g5079, doi:10.1136/bmj. g5079); News: WHO gives go ahead for experimental treatments to be used in Ebola outbreak (BMJ2014;349:g5161, doi:10.1136/bmj.g5161); Four in 10 US people fear large outbreak of Ebola (BMJ2014;349:g5321, doi:10.1136/bmj.g5321)

1 Centre for Infectious Disease Policy and Research. Angola declares worst Marburg outbreak over. Nov 2005. www.cidrap.umn.edu/news-perspective/2005/11/angola-declaresworst-marburg-outbreak-over.

2 Yong Kim J, Farmer P. What's missing in the Ebola fight in West Africa. Washington Post 31 Aug 2014. www.washingtonpost.com/opinions/whats-missing-in-the-ebola-fight-inwest-africa/2014/08/31/19d6dafc-2fb4-11e4-9b98-848790384093_story.html.

Cite this as: BMJ 2014;349:95496

๑ BMJ Publishing Group Ltd 2014 